\title{
Unconfined Compressive Strength of Clay Strengthened by Coconut Fiber Waste
}

\author{
Anita Widianti ${ }^{1}$, Willis Diana ${ }^{1}$, Zahroh Shofiyatul Fikriyah $^{1}$ \\ ${ }^{1}$ Department of Civil Engineering, Universitas Muhammadiyah Yogyakarta, Indonesia \\ *Corresponding author. Email: anitawidianti@umy.ac.id
}

\begin{abstract}
Indonesia is a country that produces the largest coconut in the world. $35 \%$ of the coconut volume is coir. Coir is a waste that has not been widely used for construction work. The coir fibers have the highest tensile strength among other natural fibers and have resistance to compressive forces. In this study, the unconfined compressive strength (UCS) of clay strengthened with coconut fiber is presented. The specimens were made with the fiber percentage of $0.00 \% ; 0.25 \% ; 0.50 \% ; 0.75 \%$; and $1.00 \%$ by weight of the mixture. This study concluded that the clay's UCS has increased along with the more coconut fiber added. The maximum value of UCS and secant modulus was obtained in clay with fibers of $0.75 \%$. The clay strengthened with coconut fiber becomes stiffer than the initial clay, thereby improving its soil stability.
\end{abstract}

Keywords—clay, unconfined compressive strength, secant modulus, coconut fiber

\section{INTRODUCTION}

Clay is one type of soil that is less profitable because it is highly influenced by moisture content, has low permeability, low bearing capacity, and slow consolidation process. Therefore, it is necessary to stabilize the soil to improve its physical and mechanical properties. Many studies currently utilize waste from natural materials as reinforcement materials or additives mixed into the soil to increase its strength. The main advantages of this natural material are that it is easy to be obtained, cheaper, and biodegradable, so it does not cause environmental problems [1],[2]. Coconut fiber has the highest tensile strength among all-natural fibers because it contains $54 \%$ cellulose [3]. The fiber has a high lignin content so that the degradation process is the slowest among other natural fibers. The fiber can last between 4 and 10 years [4]. Coconut fiber has a higher coefficient of friction and is more elastic compared to synthetic fibers [5][6],[7]. According to Oroh et al. [8], the fibers in coconut coir have mechanical properties that are rigid, tough, and resistant to compressive forces to withstand cracks and fractures. The strength of the fiber itself varies, depending on the size of the diameter and the degree of defects that exist in the fiber. If they are mixed thoroughly, these fibers will work optimally throughout the soil layer [9].

Soil reinforced using randomly distributed fibers behaves as a composite material, which is then known as the ecocomposite [4]. This behavior is like the roots of plants that contribute to the strength of the soil. Fibers with sufficiently high tensile strength will help soil that only has compressive strength [4]. There have been many studies on the effect of fiber inclusions randomly in the soil. The effect of fiber orientation, which includes random, horizontal, and vertical, is proven not to affect the Unconfined Compression Strength (UCS) value of sand soil [10].

Himanshu et al. [11] conducted CBR and UCS tests on low plasticity clay (CL) mixed with coir fiber. The value of UCS increases with increasing fiber. The maximum increase occurred in soil mixed with fiber as much as $0.75 \%$. The same results were obtained from the UCS research conducted on highly compressible clay [12]. In Venkatesh et al.'s research, the maximum value was obtained at $1 \%$ fiber [13], while the Upadhyay and Singh study obtained the maximum value at $1.5 \%$ fiber [14]. Menezes et al. [15] conducted a UCS test on clayey sand soil. The highest UCS was obtained at the fiber content of $0.5 \%$, namely $635.4 \mathrm{kPa}$ or an increase of $50.78 \%$ of the soil original. Several studies conducted UCS tests from soil mixed with coir fiber and other materials, including lime [16], using a mixture of bentonite, lime, gypsum [17], rice husk ash [6],[18],[19], fly ash [20], lime and coir fiber ash [16], carbon tetrachloride \& sodium hydroxide [21], polypropylene fiber [22], basalt fiber [23], organic polymers and sisal fiber [24]. Widianti et al. [25] have studied direct shear strength on clay strengthened with coconut fiber. The maximum shear strength is generated at fiber content of $0.75 \%$.

This study was carried out to add coconut fiber waste to the UCS of clay and obtain the optimum fiber content to produce UCS's maximum value. 


\section{RESEARCH METHODOLOGY}

\subsection{Soil}

Soil samples were collected from Kulon Progo, Yogyakarta, Indonesia (Fig. 1). Widianti et al. [25] have tested the soil's engineering properties in previous studies, as shown in Table 1. Table 1 shows that the clay which was used is high plasticity clay. Therefore, it has a low bearing capacity.

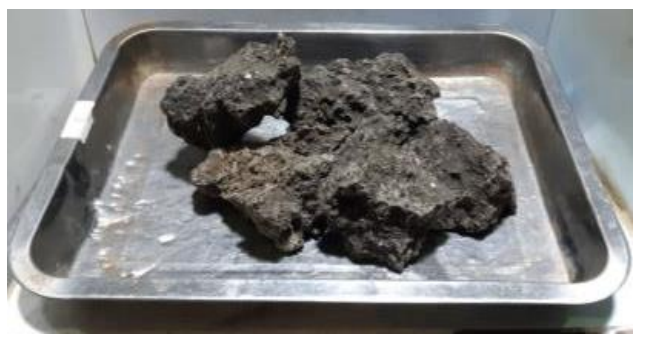

Fig. 1. Clay soil

Table I. The Engineering Properties of the Soil Samples [25]

\begin{tabular}{|c|c|c|}
\hline Parameters & Values & $\begin{array}{c}\text { Method } \\
\text { Standard }\end{array}$ \\
\hline Specific Gravity, Gs & 2.63 & $\begin{array}{c}\text { ASTM } \\
\text { D854-10 }\end{array}$ \\
\hline $\begin{array}{l}\text { Particle sizes distribution: } \\
\text { Sand }(\%) \\
\text { Silt }(\%) \\
\text { Clay }(\%)\end{array}$ & $\begin{array}{l}13.36 \\
70.58 \\
16.06\end{array}$ & $\begin{array}{c}\text { ASTM } \\
\text { D422-63 } \\
\text { ASTM } \\
\text { D6913-04 }\end{array}$ \\
\hline $\begin{array}{l}\text { Consistency limits: } \\
\text { Liquid Limit, LL (\%) } \\
\text { Plastic Limit, PL (\%) } \\
\text { Shrinkage Limit, PL (\%) } \\
\text { Plasticity Index, PI (\%) }\end{array}$ & $\begin{array}{l}89.91 \\
38.86 \\
16.33 \\
51.05\end{array}$ & $\begin{array}{c}\text { ASTM } \\
\text { D4318-10 }\end{array}$ \\
\hline $\begin{array}{l}\text { Proctor standard } \\
\text { compaction: } \\
\text { Maximum Dry Density, } \\
\text { MDD }\left(\mathrm{kN} / \mathrm{m}^{3}\right) \\
\text { Optimum Moisture } \\
\text { Content, OMC }(\%)\end{array}$ & $\begin{array}{l}12.64 \\
29.90\end{array}$ & $\begin{array}{c}\text { ASTM } \\
\text { D698-12 }\end{array}$ \\
\hline Soil Classification (USCS) & $\begin{array}{l}\mathrm{CH} \text { (inorganic clays of } \\
\text { high plasticity, fat clays) }\end{array}$ & $\begin{array}{c}\text { ASTM } \\
\text { D2487-11 }\end{array}$ \\
\hline $\begin{array}{l}\text { Soil Classification } \\
\text { (AASHTO) }\end{array}$ & A-7-6 (clayey soils) & $\begin{array}{c}\text { ASTM } \\
\text { D3282-09 }\end{array}$ \\
\hline Activity & $\begin{array}{c}3,18(>1.25, \text { active } \\
\text { clays/montmorilonite })\end{array}$ & \\
\hline
\end{tabular}

\subsection{Coconut Fibers}

Coconut fibers were mostly obtained from waste in the traditional market (Fig. 2). The fiber's tensile strength showed in Table 2. It can be concluded that coconut fiber has high tensile strength, so it is expected that the fiber can increase the soil's bearing capacity.

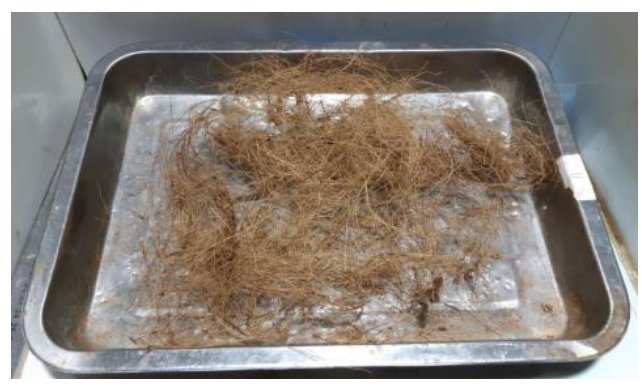

Fig. 2. Coconut Fibers
Table II. The Tensile Strength of the Coconut Fibers

\begin{tabular}{|c|c|c|c|c|}
\hline $\begin{array}{l}\text { Sample } \\
\text { number }\end{array}$ & $\begin{array}{c}\text { Diameter } \\
(\mathrm{mm})\end{array}$ & $\begin{array}{c}\text { Length } \\
(\mathrm{mm})\end{array}$ & $\begin{array}{c}\mathbf{S} \square \square \square \square \square \\
\square(\boldsymbol{\%})\end{array}$ & $\begin{array}{c}\text { Tensile } \\
\text { strength } \\
(\mathrm{MPa})\end{array}$ \\
\hline 1 & 0.0272 & 100 & 30.97 & 225.0 \\
\hline 2 & 0.0313 & 100 & 2053 & 240.8 \\
\hline 3 & 0.0411 & 100 & 34.10 & 1472 \\
\hline 4 & 0319 & 100 & 27.80 & 107.4 \\
\hline 5 & 0.208 & 100 & 3260 & 121.6 \\
\hline \multicolumn{3}{|r|}{ Average } & 29,20 & 168.4 \\
\hline
\end{tabular}

\subsection{Mix Design}

The fibers were cut into small pieces, from 30 to $50 \mathrm{~mm}$ in length, and then were randomly mixed into the soil until it is homogeneous. The coconut fiber content variations used were $0.25 \%, 0.5 \%, 0.75 \%$, and $1.0 \%$ of the mixture's weight under the conditions of optimum moisture content (OMC) and maximum dry density (MDD). Two specimens were made for each mixture.

\subsection{Testing Procedure}

The primary test in this study is the unconfined compression test referring to ASTM D2166-16 [26]. The specimens have a height of $68 \mathrm{~mm}$ and a diameter of $35 \mathrm{~mm}$ (Fig.3).

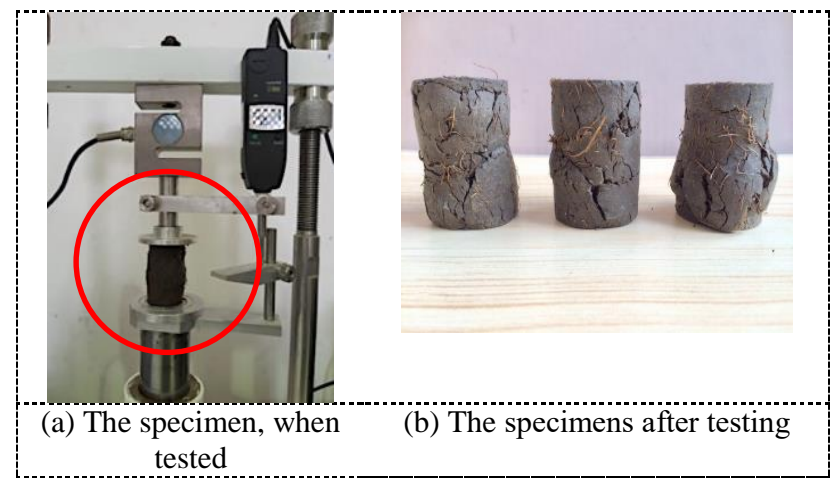

Fig. 3. The specimens

\section{RESULT AND ANALYSIS}

\subsection{Effect of Coconut Fiber on Unconfined Compressive Strength}

According to ASTM [26], the Unconfined Compressive Strength (UCS) is the maximum axial stress value withheld by the cylindrical specimen before collapsing or experiencing $15 \%$ axial strain. The UCS test results of the soil strengthened with varied coconut fiber content can be seen in Fig. 4. 


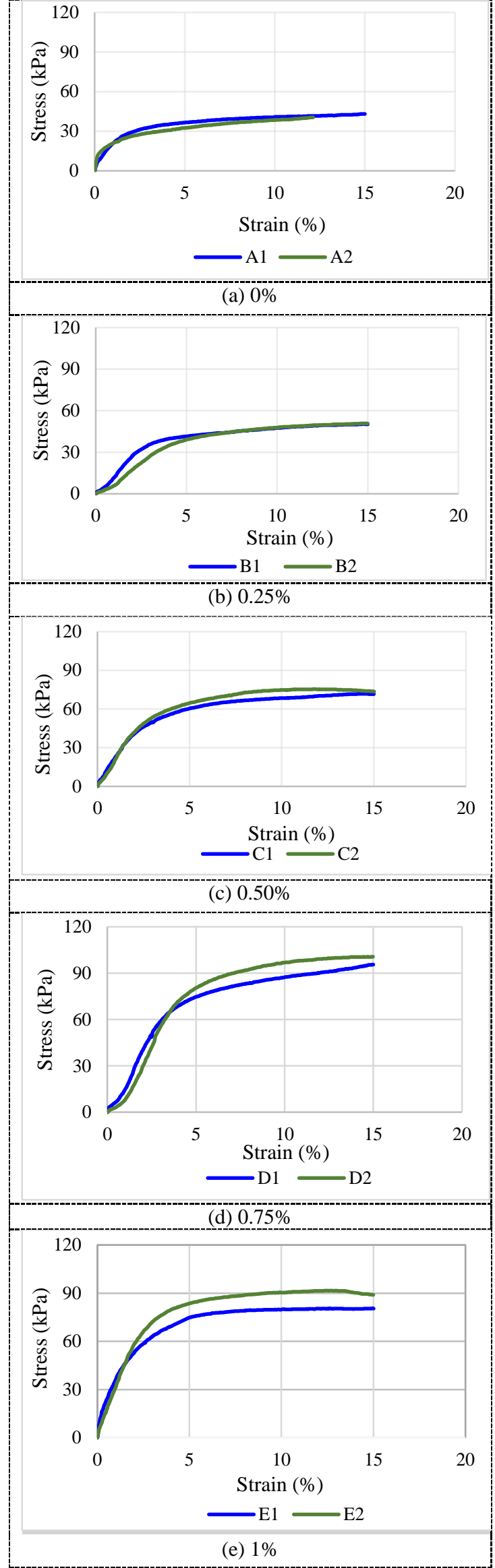

Fig. 4. The relationship between axial strain and soil stress with varying fiber content
Based on Fig. 4, each mixture's UCS value can be determined, as shown in Fig. 5.

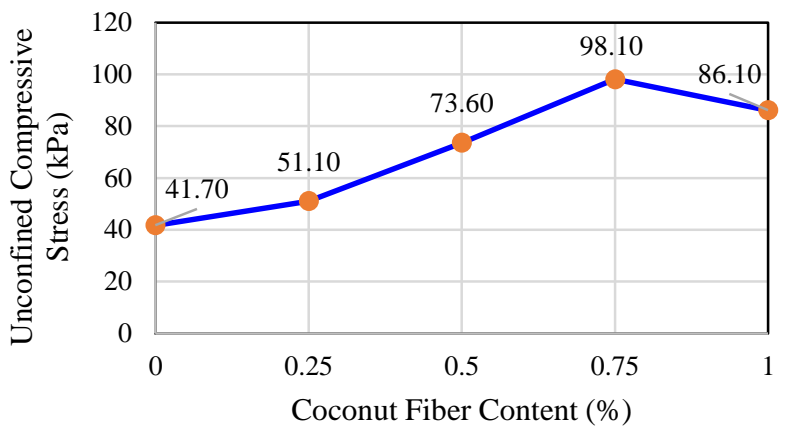

Fig. 5. The clay's UCS is strengthened by varied fiber content

Fig. 5 shows that reinforcement with coconut fibers can increase the UCS value of the soil. Before mixing with fiber, the UCS value in clay was $41.70 \mathrm{kPa}$. This value enhances the enhancing amount of coconut fiber. The maximum UCS value has occurred at the fiber content of $0.75 \%$, which was $135.25 \%$. These results are the same as research conducted by Himanshu et al. [11] and Sujatha et al. [12], which says that the optimum fiber content is $0.75 \%$. According to Menezes et al. [15], the soil becomes active when subjected to external loads. This behavior will increase the interaction between soil and fiber so that the strength of the composite increases. However, the fiber that exceeds the optimum amount will reduce its strength because the fibers will interact with each other, not with the soil.

Based on the UCS value, clay soil consistency can be classified [27]. Initially, clay, which has a UCS value of 41.70 $\mathrm{kPa}$, is classified as soft soil. With the addition of coconut fiber, the mixture is classified as stiff clay.

\subsection{Effect of Coconut Fiber on Secant Modulus $\left(E_{50}\right)$}

Secant modulus is the value of stress resistance at $50 \%$ before the test object deforms. Based on the UCS value and Fig. 4, the secant modulus value can be calculated (Fig. 6).

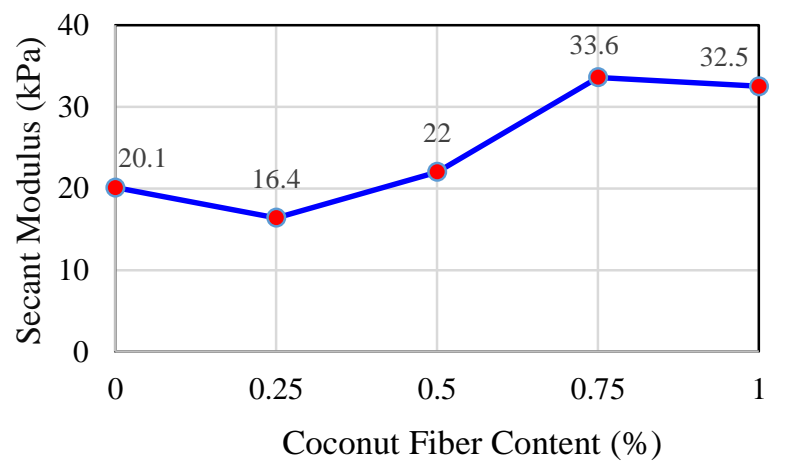

Fig. 6. The clay's secant modulus is strengthened by varied fiber content

Fig. 6 shows the secant modulus $\left(\square_{50}\right)$ increase with increasing fiber content. This increasing value of $\mathrm{E}_{50}$ shows that the mixture is getting stiffer [28]. The results showed that 
the secant modulus increased from $20.10 \mathrm{kPa}$ to $33.60 \mathrm{kPa}$ in $0.75 \%$ coconut fiber mixture, increased by $153 \%$ compared to the sample without added fiber. However, if the fiber content is more than $0.75 \%$, the secant modulus will decrease. One of the factors affecting the secant modulus is the bond between soil grains. If there are too many fibers, the bonds between grains are reduced.

\section{CONCLUSION}

1. The value of the unconfined compressive strength of clay has increased along with the more coconut fiber added.

2. The maximum value of unconfined compressive strength and secant modulus obtained in clay with coconut fiber reinforcement is $0.75 \%$ of the mixed soil weight

3. The clay strengthened with coconut fiber becomes stiffer than the initial soft clay, thereby improving its soil stability.

In further research, it is necessary to test the durability of a mixture of soil and coconut fiber. In further research, it is necessary to test the durability of a mixture of soil and coconut fiber.

\section{ACKNOWLEDGMENT}

This paper is part of research sponsored by Universitas Muhammadiyah Yogyakarta, Indonesia, in 2019-2020 under the research grant number 034/PEN-LP3M/I/2020.

\section{REFERENCES}

[1] R. R. Singh and E. S. Mittal, "Improvement of local subgrade soil for road construction by the use of coconut coir fiber," Int. J. Res. Eng. Technol., vol. 3, no. 5, pp. 707711, 2014.

[2] N. Suffri, M. Jeludin, and S. Rahim, "Behaviour of the Undrained Shear Strength of Soft Clay Reinforced with Natural Fibre," IOP Conf. Ser. Mater. Sci. Eng., vol. 690, no. 1, 2019.

[3] G. L. S. Babu and A. K. Vasudevan, "Evaluation of strength and stiffness response of coir-fibre-reinforced soil," Proc. Inst. Civ. Eng. Improv., vol. 11, no. 3, pp. 111-116, 2007.

[4] S. M. Hejazi, M. Sheikhzadeh, S. M. Abtahi, and A. Zadhoush, "A simple review of soil reinforcement by using natural and synthetic fibers," Constr. Build. Mater., vol. 30, pp. 100-116, 2012.

[5] P. M. Chaple and A. I. Dhatrak, "Performance of coir fiber reinforced clayey soil," Int. J. Eng. Sci., vol. 2, no. 4, pp. 54-64, 2013.

[6] T. Subramani and D. Udayakumar, "Experimental study on stabilization of clay soil using coir fibre," Int. J. Appl. or Innov. Eng. Manag., vol. 5, no. 5, pp. 192-204, 2016.

[7] H. K. Gupta, M. C. Maurya, and A. K. Gupta, "Shear Strength Enhancement of Soil by Using Coconut Fiber," vol. 3, no. 6, pp. 366-372, 2017.

[8] J. Oroh, F. P. Sappu, and R. C. Lumintang, "Analisis sifat mekanik material komposit dari serat sabut kelapa," $J$. Online Poros Tek. Mesin Unsrat, vol. 1, no. 1, 2013.

[9] S.-S. Park, "Effect of fiber reinforcement and distribution on unconfined compressive strength of fiber-reinforced cemented sand," Geotext. Geomembranes, vol. 27, no. 2, pp. 162-166, 2009.
[10] J. D. Nyuin, N. S. Khalil, and C. Petrus, "Performance of Sand Reinforced with White Coir Fibre," IOP Conf. Ser. Mater. Sci. Eng., vol. 429, no. 1, 2018.

[11] B. Himanshu, N. Jauhari, and H. Varshney, "Performance and Analysis of Coir Fibre as Soil Reinforcement," Int. J. Res. Appl. Sci. Eng. Technol., vol. V, no. XI, pp. 62-72, 2017.

[12] E. R. Sujatha, S. Sai, C. Prabalini, and Z. F. Aysha, "Influence of random inclusion of coconut fibres on the short term strength of highly compressible clay," in IOP Conf. Series: Earth and Environmental Science, 2017, pp. $1-6$.

[13] A. Venkatesh, S. Anwer, M. R. Suprith, M. S. Sachin, and D. R. Goutham, "Experimental Investigation on Expansive Soil Stabilized Using Coir Fibre," vol. 7, no. 1, pp. 65-70, 2019.

[14] P. Upadhyay and Y. Singh, "Soil stabilization using natural fiber coir," Int. Res. J. Eng. Technol. e-ISSN, pp. 56-2395, 2017.

[15] L. C. P. de Menezes, D. B. de Sousa, S. F. Sukar, and S. R. de M. Ferreira, "Analysis of the Physical-Mechanical Behavior of Clayey Sand Soil Improved with Coir Fiber," Soils and Rocks, vol. 42, no. 1, pp. 31-42, 2019.

[16] G. Narendra Goud, A. Hyma, V. Shiva Chandra, and R. Sandhya Rani, "Expansive soil stabilization with coir waste and lime for flexible pavement subgrade," IOP Conf. Ser. Mater. Sci. Eng., vol. 330, no. 1, 2018.

[17] R. K. Dutta and B. Mohanty, "Effect of coir fibres on the compaction and unconfined compressive strength of bentonite-lime-gypsum mixture," Slovak J. Civ. Eng., vol. 23, no. 2, pp. 1-8, 2015.

[18] S. P. K. Kodicherla and D. K. Nandyala, "Influence of randomly mixed coir fibres and fly ash on stabilization of clayey subgrade," Int. J. Geo-Engineering, vol. 10, no. 1, pp. 1-13, 2019.

[19] R. Kumar, "Experimental Study of Coir Fiber \& Rice Husk Ash on Geotechnical Properties of Expansive Soil," Int. J. Res. Appl. Sci. Eng. Technol., vol. 7, no. 12, pp. 996-1005, 2019.

[20] Sachin. D, A. Mujeeb, and Dr. Sowmya N. J, "Effect of Coconut Coir Fibres on Black Cotton Soil Blended with Fly Ash," Int. J. Eng. Res., vol. V5, no. 10, pp. 505-508, 2016.

[21] R. K. Dutta, V. N. Khatri, and V. Gayathri, "Effect of addition of treated coir fibres on the compression behaviour of clay," Jordan J. Civ. Eng., vol. 159, no. 700, pp. 1-13, 2012.

[22] G. M. Ayininuola and P. O. Oladotun, "Geotechnical properties of coconut coir fiber soil mixture," J. Civ. Eng. Res., vol. 6, no. 4, pp. 79-85, 2016.

[23] L. Gao, G. Hu, N. Xu, J. Fu, C. Xiang, and C. Yang, "Experimental study on unconfined compressive strength of basalt fiber reinforced clay soil," Adv. Mater. Sci. Eng., 2015.

[24] Y. Bai et al., "Unconfined compressive properties of composite sand stabilized with organic polymers and natural fibers," Polymers (Basel)., vol. 11, no. 10, 2019.

[25] A. Widianti, W. Diana, and M. Hasana, "Direct Shear Strength of Clay Reinforced with Coir Fiber," UKaRsT, vol. 4, no. 2, pp. $151-162,2020$

[26] ASTM International, "ASTM D2166 / D2166M-16," in Standard test method for unconfined compressive strength of cohesive soil., West Conshohocken, USA, 2016.

[27] B. M. . Das and K. Sobhan, Principles of Geotechnical Engineering. Boston, USA: Cengage Learning, 2016.

[28] G. Ranjan and A. Rao, "Basic and Applied Soil Mechanics. New Age International.” 2000. 